УДК 372.881 .111 .1

DOI: 10.17277/voprosy.2017.02.pp.113-120

\title{
THE FOREIGN LANGUAGE ASSESSMENT SYSTEM IN HIGHER EDUCATIONAL INSTITUTIONS OF DIFFERENT COUNTRIES
}

\author{
L. Yu. Korolyova \\ Tambov State Technical University, Tambov, Russia \\ Reviewed by Doctor of Pedagogic Sciences, \\ Professor R. P. Milrood
}

Keywords: assessment tools and resources; exit exams; foreign language assessment system; higher educational institution; language skills; oral proficiency interview; performance assessment.

\begin{abstract}
The problem of assessing foreign language learners' skills is focused on. The definition of the term 'assessment' as well as types of assessment and their peculiarities are given. Different approaches to evaluating students' knowledge of foreign languages are considered. Performance-based assessment and its advantages are discussed. Much attention is paid to Oral Proficiency Interview as one of the most appropriate methods to assess University students' language skills relying on the correlation of foreign languages with real-life situations. Foreign language assessment systems of the USA, Europe and Russia are analyzed. The study of assessment types used at Tambov State Technical University is carried out. The results show that paper-and-pencil tests made by teachers are the most widely used method of evaluation as well as exit exams.
\end{abstract}

\section{Introduction}

The system of assessing foreign language learners' knowledge is changing constantly according to educational standards and requirements of the time. It is rather difficult to develop a uniform perfect system for evaluating students' language skills but history shows that recently there have appeared tendencies towards the connection of language skills and realities in which a language functions. Let us consider the foreign language assessment system on the whole and the system used in higher educational institutions of the USA, Europe and Russia in particular.

Королева Людмила Юрьевна - кандидат филологических наук, доцент кафедры «Международная профессиональная и научная коммуникация», e-mail: lyu-korolyova@yandex.ru, ТамбГТУ, г. Тамбов, Россия.

УНИВЕРСИТЕТ им. В.И. ВЕРНАДСКОГО. №2(64). 2017. 
Accoridng to the definition of the term 'assessment', it "is a systematic process of gathering information about what a student knows, is able to do, and is learning to do. Assessment information provides the foundation for decisionmaking and planning for instruction and learning. Assessment is an integral part of instruction that enhances, empowers, and celebrates student learning" [1].

Using a variety of assessment techniques, teachers gather information about what students know and are able to do, and provide positive, supportive feedback to students. They also use this information to diagnose individual needs and to improve their instructional programs, which in turn helps students learn more effectively.

There are three types of assessment: diagnostic, formative and summative. Diagnostic assessment implies the preliminary evaluation of students' language skills in order to find out what they know at this very stage and pay attention to those aspects which are problematic for language learners at this time.

Formative assessment can give a teacher the information about the success of his teaching and the achievement or non-achievement of his objectives. This type of assessment covers several areas:

- monitoring of students' learning;

- identification of growth areas;

- motivation of students;

- provision of practical tasks for developing language skills;

- reflection on program structure and effectiveness [1].

Summative assessment is usually used at the end of the program or unit study.

\section{The foreign language assessment system in the USA}

In American higher educational institutions it is required to evaluate and report not only on what students have learned but also how they perform with the acquired knowledge. This kind of assessment is called performance assessment. In the American system of language education they began to focus on performance assessment as opposed to the evaluation of language skills after the publication of ACTFL Proficiency Guidelines and the Oral Proficiency Interview when most teachers tried to move away from audio-lingual habit formation principle to a communicative approach concerning language learning. These two initiatives were developed to serve as a benchmark for the assessment of foreign language proficiency.

Language assessment experienced another major overhaul with the dissemination of the standards for Foreign Language Learning: Preparing for the XXI Century. The standards designated the content of language learning and the abilities that the students should develop as a result of foreign languages instructions [2].

It was strongly recommended to use performance-based assessment. However, not all university teachers followed those instructions at that time and applied conventional methods for evaluating students' language skills. It should be noted that new trends dealt with the development of the communicative competence that implied the ability of students to use a foreign language in real 
situations. Therefore language teachers had to concentrate on the process of engaging students in such activities which corresponded to and reflected people's everyday needs and ways of meeting them through the use of a foreign language.

At the beginning of the $21^{\text {st }}$ century, Oral Proficiency Interview was introduced into the foreign language assessment system in the USA. The objective of the interview was to determine a student's level of proficiency without focusing on the methods used to achieve this level. It was a face-to-face tape-recorded interview taken by an experienced language teacher. It included several stages:

- a warm-up (preliminary questions to help a student adapt to the activity); level);

- level checks (to find out if a student constantly does tasks at the specific

- a role-play;

- a wind-down period (easy questions are asked).

The interview could last up to half an hour. The student's performance was scored according to the Speaking Proficiency Guidelines [2].

Other types of assessment were also introduced such as:

- self-assessment (students evaluate themselves their language skills);

- portfolio assessment (students do various assignments and collect them to show their work and progress at some definite moment; they can choose their best assignments as well);

- exit exams (students show and prove their level of proficiency at the end of a course; these exams usually cover all linguistic aspects such as Reading, Speaking, Listening, Writing);

- computer-assisted exams (students are examined according to their level which is determined by the computer);

- a capstone course project (a source of multiple assessment data);

- a service learning project (students must apply what they have learned in real life situations).

At the present moment in most universities and colleges of the USA they use faculty-designed tests, student papers and projects as well as student presentations to assess language proficiency. It is surprising but translation exercises are mostly chosen as a method used in classrooms rather than Oral Proficiency Interview (96\%).

Student portfolios are used by $38 \%$ of higher educational institutions whereas self-assessment - by $58 \%$, service learning projects - by $27 \%$, computer-assisted tests - by $30 \%$, exit exams - by $29 \%$ [2].

\section{The European system of evaluating foreign language skills}

In Europe, they tried to determine the most 'criterial' aspects of language at different levels of language ability at the end of the XX century. This resulted in the publication of the Common European Framework of Reference for Languages that describes a language that can be used in different contexts and defines the term 'a language level'. According to this document, the language 
assessment system had to focus on validity of any test. Validity in its turn covered three areas:

- construct (the underlying trait or ability being tested);

- content (the relevance and coverage of the content of the test with regard to the construct);

- criterion (how similar the results of this test are to the results of a test which focuses on the same construct) [3].

At the same time great attention was paid to the expected or unexpected consequences or impact of a test or its so called consequential validity. It was focused on test impact, social value implications and ethics.

In 2005 a new trend concentrated on a test-taker appeared. O'Sullivan showed this approach in Fig. 1 [3].

According to the scheme language assessment is based on various parameters which depend on a test developer and a test taker and consequently contribute to the performance which is examined. Let us characterize them:

- performance parameters should include such things as timing and score a student can have after having done a particular task or a test on the whole;

- linguistic demands imply the use of specific language in different situations;

- physical individual characteristics include a student's gender, age, shortterm ailments (such as cold, toothache etc.) and longer-term disabilities (e.g. dyslexia, limited hearing or sight etc.);

- psychological individual characteristics refer to memory, personality, cognitive style, concentration, motivation and emotional state as well as cognitive processes and resources;

- experiential individual characteristics depend on a student's experience of taking exams;

- cognitive processes and resources are based on a person's cognitive processes and his knowledge of the content as well as language ability;

- theoretical fit is the way test performance is assessed according to the ability being tested. This refers to an examiner selection, training, monitoring and analysis of rating behavior;
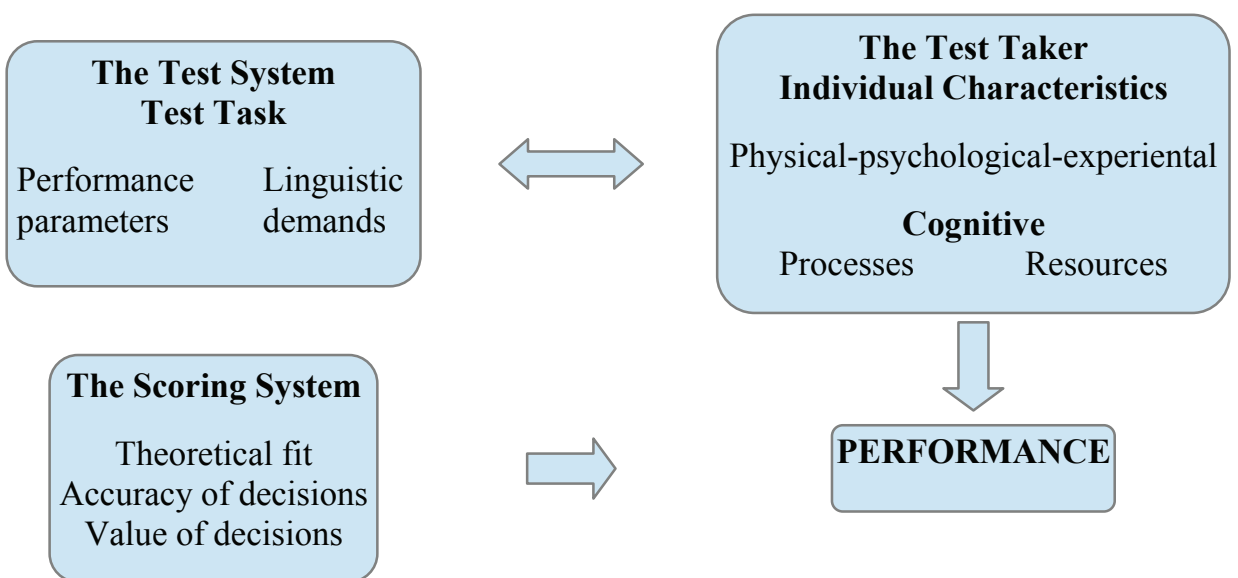

Fig. 1. Socio-cognitive basis of tests 


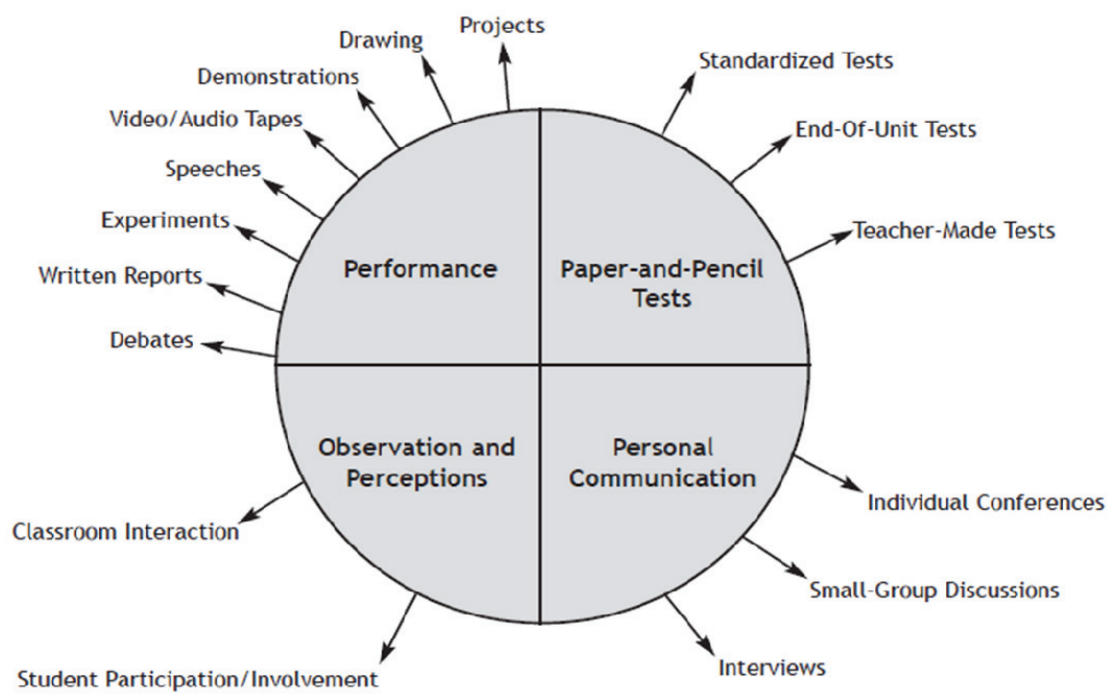

Fig. 2. Assessment tools and resources

- accuracy of decisions implies reliability and should relate to all aspects of the psychometric functioning of a test;

- value of decisions refers to criterion-related evidence (e.g. comparison with standards) [3].

Summarizing those approaches which are used in American and European higher educational institutions it can be said that firstly, they are focused on performance-based assessment and secondly, developing tests one should take into account many parameters including socio-cognitive ones. Apart from these main features, a great number of tools and resources can be used for evaluating students' performance (see Fig. 2) [1].

These tools and resources include a great variety of activities in which a student can be engaged. The main thing is to evaluate a student's progress quite objectively and in compliance with educational standards and time requirements.

\section{The foreign language assessment system in Russia}

In Russian higher educational institutions language assessment system has also seen many changes beginning with the evaluation of skills in Reading and Writing and turning to the communicative approach to teaching foreign languages and consequently assessment of Speaking and Listening as well. The most important thing is that according to educational standards of Russia students must have a number of language competences as a result of studying the program.

Let us consider competences which must be developed after having studied a foreign language (English) as a part of the Master's program "Civil Engineering" at Tambov State Technical University where English is not a major and it is learned for specific purposes, i.e. for the ability to use it in the professional field. 
In this case the following competence must be developed according to the state educational standard:

- the ability to use a foreign language for communication in oral and written forms to solve professional problems.

The course is taken in the first term and learners are expected to earn three credits doing 108 hours. The course is divided into three modules which cover such areas as "Professional communication in English", "Scientific communication in English" and "Business communication in English".

Before doing the course students take an entrance exam (test) which relates to diagnostic assessment and helps teachers find out students' knowledge of English at this stage.

\section{The study}

A study of the types of assessment used by the university teachers was carried out. They were asked to range types of assessment they use according to frequency parameters. The results of the study are shown in Table 1.

The faculty-designed tests which are mostly paper-and-pencil tests are widely used by the university language teachers. This can be explained by the fact that teachers try to develop their own tests relying on individual groups, their level of English and specific purposes for which students must learn English. From this point of view, it is clear that future civil engineers need special assignments relating to their professional fields and teacher-made tests solve the problem best of all taking into account all parameters which were discussed above.

Student presentations are often used to assess learners' language skills as they provide a very useful and effective method for the language evaluation. Making a presentation students can achieve several goals such as:

Table 1

Types of assessment of foreign languages at TSTU

\begin{tabular}{l|c|c|c|c}
\hline \multirow{2}{*}{ Types of assessment } & \multicolumn{4}{|c}{ Frequency of use, \% } \\
\cline { 2 - 5 } & always & often & seldom & never \\
\hline Faculty-designed & 98 & 2 & 0 & 0 \\
tests & 10 & 50 & 30 & 10 \\
Student presentations & 20 & 65 & 5 & 10 \\
Student portfolios & - & 10 & 85 & 5 \\
Self-assessment & 10 & 0 & 80 & 10 \\
Computer-assisted & 0 & 0 & 0 & 100 \\
exams & 100 & 0 & 0 & 0 \\
Service learning & & & & \\
projects & &
\end{tabular}


- reviewing of some professional context and structuring it;

- applying Grammar rules;

- use of appropriate vocabulary;

- making up a monologue and representing Speaking skills.

Student portfolios can be a method of assessing students' language skills especially at the end of the term when the collected assignments prove students' work and show their performance during this period of time.

Self-assessment is not widely accepted by the University language teachers as it is believed that only professional people can give a full and objective summary of somebody's work. However, sometimes when students are skilled, responsible and reliable enough this method can work.

Computer-assisted exams are not often used for evaluating students' language skills except diagnostic assessment. The main reason is that such tests are mostly grammar and vocabulary ones and the main components of any foreign language are not checked.

The University teachers do not apply service learning projects as they are not common in Russia. A new system of relationships between different civil and educational institutions is required to put this idea into practice.

As for exit exams they provide the most popular and reliable method of assessment at the end of the course at the present time because they have been used in Russian higher educational institutions for a long time. The requirements for students' knowledge are changing constantly. However these exams include evaluation of all four language components: Reading, Writing, Speaking and Listening.

If we look at Fig. 2, we can say that paper-and-pencil tests is the most popular method of continuous assessment at Tambov State Technical University besides all other tools and resources among which we can single out smallgroup discussions, interviews, debates and written reports.

\section{Conclusion}

In conclusion, it should be noted that the language assessment system in the USA, Europe and Russia is practically the same except some nuances which relate to educational traditions in every country. But on the whole the main principle of evaluating students' language skills is performance-based one. It requires language proficiency in all four language aspects so that students can apply their knowledge in professional fields.

\section{References}

1. Classroom assessment, available at: http://www.edu.gov.mb.ca (accessed: 26 January 2017).

2. Ricardo-Osorio J.G. A study of foreign language learning outcomes assessment in US undergraduate education, 2008, available at: web.pdx.edu (accessed: 24 January 2017).

3. O'Sullivan B. East Asia. New Directions: Assessment and Evaluation. A collection of papers, 2011, pp. 15-25, available at: http://www.teachingenglish (accessed: 26 January 2017). 


\section{Список литературы}

1. Classroom assessment [Электронный pecypc]. - Режим доступа: http://www.edu.gov.mb.ca (дата обращения: 26.01.2017).

2. Ricardo-Osorio, J. G. A Study of Foreign Language Learning Outcomes Assessment in US Undergraduate Education [Электронный ресурс] / J. G. RicardoOsorio. - 2008. - Режим доступа: web.pdx.edu (дата обращения: 24.01.2017).

3. O'Sullivan, B. Theories and Practices in Language Testing [Электронный pecypc] / B. O'Sullivan // East Asia. New Directions: Assessment and Evaluation. A Collection of Papers. - 2011. - P. 15 - 25. - Режим доступа: http://www. teachingenglish (дата обращения: 26.01.2017).

\section{Система оценивания иностранных языков в высших учебных заведениях разных стран}

\section{Л. Ю. Королева}

ФГБОУ ВО «Тамбовский государственный технический университет», г. Тамбов, Россия

Ключевые слова: выпускные экзамены; высшее учебное заведение; оценка эффективного применения полученных знаний; оценочные инструменты и ресурсы; практические навыки; система оценивания иностранных языков; устное собеседование, языковые навыки.

Аннотация: Рассмотрена проблема оценивания навыков студентов, изучающих иностранные языки. Трактовано определение термина «оценивание», даны описания видов оценивания и их особенностей. Проанализированы подходы к оценке знаний студентов по иностранным языкам с акцентированием внимания на способе оценки эффективного применения полученных знаний и его преимуществах. Выделено устное собеседование, проверяющее практические навыки, как наиболее подходящий метод оценки языковых навыков студентов вузов, основанный на соотнесении знаний по иностранным языкам с реальными жизненными ситуациями. Рассмотрены системы оценивания иностранных языков в США, Европе и России. Проведено исследование типов оценивания, применяющихся в Тамбовском государственном техническом университете, в результате которого сделан вывод о том, что письменные тестовые задания, составленные преподавателями вуза, и выпускные экзамены наиболее широко применяются для оценки знаний студентов по иностранным языкам.

(С) Л. Ю. Королева, 2017 